The Northern Review

yukoncollege.yk.ca/review

\title{
Situating Educational Issues in Nunavut: Perceptions of School Leaders and Teachers
}

Jane P. Preston

\begin{abstract}
The purpose of this article is to describe some educational contexts and challenges experienced by students and educators who live in Nunavut. The data for this qualitative study include twenty-four semi-structured interviews involving fourteen principals, vice-principals, and teachers from Nunavut. Four themes surfaced: student attendance, legacy of residential schools, lack of Inuktitut/Inuinnaqtun resources, and transient teachers. With regard to student attendance, participants viewed this issue as one of the most challenging aspects of their education system. Second, participants emphasized that the Nunavut Department of Education was promoting fluent Inuktitut/Inuinnaqtun and English learners. While participants valued the importance of maintaining the vitality of the Inuit language, they believed resources to promote the Inuit language were limited. Third, many principals indicated that the legacy of residential schools was a reason some school-parent relationships lacked an element of trust. Last, participants explained that the constant teacher turnover caused relational strains between educators, students, parents, and community members. Cultural compatibility theory was employed as the philosophical basis to conceptualize findings. This theory assumes that a student needs an educational experience where that learner can see, feel, hear, taste, and touch his/her cultural values and beliefs. The design of educational programs need to foster the unique identities of Inuit peoples through the implementation of curricula built upon local Inuit culture, language, and knowledge. In doing so, attendance issues within school can be addressed, for example. Also, when parents see their culture within the school curriculum and environment, they will feel more welcomed and at home in this familiar context.
\end{abstract}




\section{Introduction}

This article is part of a larger research project that documented the practices of Nunavut principals and teachers who foster educational achievement for Indigenous students throughout Nunavut, Prince Edward Island, and Saskatchewan (see Preston, Claypool, Rowluck, \& Green, 2015, 2016, in press). A refined objective of that study was to identify personal, professional, and institutional successes and challenges of participants who lived in Nunavut. In turn, the purpose of this article is to describe some educational contexts and challenges experienced by students and educators who live in Nunavut. This qualitative study included twentyfour semi-structured individual interviews involving principals, viceprincipals, and teachers from Nunavut. The findings highlight issues pertaining to attendance, legacy of residential schools, lack of Inuktitut/ Inuinnaqtun resources, and transient teachers. Cultural capability theory is the philosophical basis used to discuss the findings. As a part of cultural capability theory (Demmert, 2004; Ladson-Billings, 1994), school curricula must reflect the physical, mental, emotional, and spiritual culture of the local school community. When this driving cultural force is not both blatantly obvious and directly and tacitly expressed within the school environment, students are demotivated to participate in a culturally uncomfortable learning context.

The research focus and its findings are important for many reasons. First, because the median age of Inuit people is so young, a vast proportion of the Inuit population is currently enrolled in Kindergarten to Grade 12 education. Consequently, the findings of this study relate to a large group of the Nunavut population. Second, as compared to the Canadian population, Inuit peoples have substantially lower Grade 12 graduation rates. Although exact numbers of Grade 12 completion numbers vary, Statistics Canada (2016) states that $42 \%$ of Inuit people aged between 18 and 44 have a high school diploma or equivalent. This number compares to $88 \%$ for non-Aboriginal Canadians. The Amaujaq National Centre for Inuit Education (2014) reports that, in some communities, 75\% of Inuit students do not graduate from Grade 12. Related to this point, the vision of the Government of Nunavut's Inuit Employment Plan (n.d) is to ensure the "government workforce is representative of the population it serves. [By] 2020, Nunavut [will be] a place where Inuit have been supported in their training and have taken leadership roles in governments and in our communities" (II3). If, by 2020, the government's workforce is to reflect the population it serves, then improving the education and training experiences of the young burgeoning group of Inuit students, in current 
day, is of extreme importance. In turn, the results of this study are meant to empower teachers, school leaders, policy-makers, and other leaders in Nunavut with insight to enhance Inuit student success so current students will be future Nunavut leaders.

Until the mid-twentieth century, the Inuit were self-sufficient, living from the bounty of the land. During the 1950s, the Canadian government established a physical presence in the Arctic. This outsider dominance was partially motivated by a federal initiative to increase Canadian military security after the Cold War, as well as by an intention to commercially mine natural resources entombed in the Arctic (Rodon \& Lévesque, 2015). Communities in the Far North needed to be established. To achieve this aim, the federal government established the Department of Northern Affairs and Natural Resources ${ }^{1}$ in 1953 (Bonesteel, 2006). Also, during this time, in an effort to reinforce Canadian sovereignty in the North, Inuit families were relocated from their traditional hunting grounds to new federally-established communities: "Relocated families were moved to small, poorly heated and [poorly] insulated accommodations" (RuizCastell et al., 2015, p. 122). Inuit children were forcefully taken from their families and sent to compulsory residential schools, where the use of English-only language and English-only curricula were mandated and strictly enforced. These colonial encounters were unidirectional, and the Inuit culture was absorbed into the powerful structure of the Canadian government. Throughout this time, the colonial enterprise was meant to establish dominance over uncivilized land. Lévesque (2014) explained, "Western powers were giving 'primitive' peoples-who were deemed to disappear in the short term anyway-salvation" (p. 126). Through these unjust acts of colonization, what was once an unrestricted, land-reverent, self-sustaining Inuit lifestyle was largely replaced by one dependent on Western goods such as clothing, foodstuffs, weapons, tools, and technical equipment.

Due to historical and ongoing acts of colonization, many Inuit people now face social and educational challenges. In 2013, the employment rate for working-age Inuit was $59 \%$, compared to $76 \%$ for non-Aboriginal people in the same age group (Statistics Canada, 2013). Suicide rates for Inuit youth are eleven times the national Canadian average and are among the highest in the world (Health Canada, 2015). Food insecurity is a welldocumented crisis among Inuit (Rosol et al., 2011). In 2012, 41\% of Inuit aged 15 and older lived in households that experienced food insecurity (Ruiz-Castell et al., 2015). In northern Canada, expenses for basic needs such as food, housing, and clothing are much higher than in southern 
Canada. For example, in Nunavut it costs about $\$ 350-\$ 450$ a week to provide a healthy diet for a family of four, compared to about $\$ 200$ in the south (Gionet, 2014). Furthermore, as Peritz (2014) reported, the median annual income for Inuit who live in Nunavut is $\$ 19,900$, compared to $\$ 86,600$ for non-Aboriginal people living in Nunavut. People with lowor poverty-level incomes commonly experience less than ideal health, a higher prevalence of disease, and shortened life expectancy (Tjepkema, Wilkins, \& Long, 2013). In line with this information, only $45 \%$ of Inuit aged 15 and older reported very good or excellent health, as compared to $63 \%$ in the same age range for Canada as a whole (Wallace, 2014). Also, many health issues are predicated on lack of housing and inadequate housing. Statistics Canada (2015) has defined crowding as more than one person per room (e.g., six people living in a five-room house); using this metric, $25 \%$ of Inuit live in crowded households, as compared with 3\% of the Canadian population. Lack of adequate housing and crowding issues result in the spread of infectious diseases, respiratory tract infections in infants, and social problems such as family violence (Ruiz-Castell et al., 2015). It is within this demographic context that the research for this study was undertaken.

Nunavut has faced a number of additional challenges specifically related to education. McGregor (2011) indicated, "Early school leavers, truancy, and lateness have always been significant challenges to student success in every community in Nunavut" (p. 17). According to Government of Nunavut data, the student attendance rate for the 2013-2014 school year in the community of Arviat, for example, was $63 \%$, compared to a $71 \%$ average student attendance rate across the Nunavut territory (CBC News, 2015). Also, as mentioned above, the legacy of residential schools still influences modern education. Daitch (2015) described the impact from residential schools: "the state's attempt to brainwash children-by forcing the dominant culture on themdevastated Aboriginal communities in Canada" (II4). Canada's residential schools exemplify a racist initiative that has, understandably, contributed greatly to the distrust between educational authorities and teachers, and some Inuit people. In addition, the Nunavut educational system is faced with a shortage of Inuit teachers and lack of Inuktitut/Inuinnaqtun resources (Berger \& Epp, 2005; McGregor, 2012; Office of the Auditor General of Canada, 2013). Less than 30\% of teachers in Nunavut are Inuit (Manning, 2013), and almost all teachers in middle and high school are from southern Canada (Aylward, 2007). Most teachers who come from the south or outside of Nunavut do not stay in Nunavut for an extended 
period of time (Manning, 2013); consequently, students are constantly required to establish relationships with a never-ending host of new teachers. Moreover, many of these new teachers lack teaching experience or knowledge of the Inuit culture.

\section{Cultural Compatibility Theory}

Rather than analyzing the findings of this study through a theoretical model that assumes components of colonial hegemony, cultural compatibility theory was used as the conceptual approach. Cultural compatibility theory (Blake, 2004; Demmert, 2004; Nile, Byers, \& Kruegar, 2007; Yamauchi, 1998) emphasizes that there needs to be cultural consistency between home and school experiences. This theory stresses the importance of nurturing the student's culture and customs while simultaneously promoting high-quality education. Furthermore, central to cultural compatibility theory is the principle of congruence-the belief that when values and expectations of the classroom are harmonious with those of, for example, in an Inuit community, student participation and learning improves (Demmert, 2004; Yamauchi, 1998). In other words, when a child is immersed in an educational environment that is culturally compatible with the values of the community, learning prospects are improved (Demmert, 2004; Yamauchi, 1998). The concept also includes components of Ladson-Billings' (1994) ideas, highlighting the importance of culturally relevant pedagogy "that empowers students intellectually, socially, emotionally, and politically by using cultural referents to impart knowledge, skills, and attitudes" (pp. 17-18). Using the concepts of cultural compatibility theory means recognizing the importance of giving Inuit people and their communities a decisive voice in determining what programs are most suitable for their youth's educational context. Applying these ideas to a Nunavut context, Alyward (2012) provided a suggestion to

Nunavut educators: "Education needs to be firmly anchored in Nunavut communities, on the land, outside classrooms, such that cultural and linguistic maintenance is possible" (p. 223).

\section{Research Methodology}

This research assumes a qualitative methodology, because both the purpose of the study and its data reflect situational, dynamic, social, and person-focused issues. This qualitative research reflects how people construct meaning from individualized life experiences (Patton, 2015). Qualitative researchers acknowledge the existence of multiple constructed 
realities and attribute thematic meanings to the various perceptions and life experiences of participants. Participants in this study described the educational context and barriers that they perceived Inuit students experience in Nunavut schools. The findings reflect the participants' languages and personalized stories; therefore, the thematic results are actual quotations extracted from interview transcripts, and participant experiences as paraphrased from interview transcripts.

This research involved twenty-four semi-structured individual interviews with fourteen educators living in seven different communities located across the three regions of Nunavut (i.e., Kivalliq, Kitikmeot, and Qikiqtani). Examples of interview questions included the following:

- How would you describe the school's climate?

- How does your school culture embody Inuit language, culture, and ways of knowing?

- What kinds of professional development topics, opportunities, or goals are promoted for staff?

- What kinds of professional development do you undertake or want for yourself?

- What kinds of relationships do the staff in your school have with the students and parents of Inuit students?

- What are some challenges you face as you promote the educational success and well-being of Inuit students?

- What institutional challenges or barriers (e.g., financial, power, political) might you experience as you try to support student achievement and well-being for Inuit students?

- To support Inuit students in school, if you could have any type of educational supports you wanted, what would they be?

- What short-term and long-term changes need to take place in your school to ensure that more Inuit students graduate from Grade 12?

Participants included eight principals, two vice-principals, and four teachers. At the time of the interviews, participants possessed from five years to a lifetime of experience living and/or teaching in Nunavut. To find participants, purposeful sampling was used (Marshall \& Rossman, 2011; Patton, 2015). Initially, participants were delimited to principals who had two or more years of experience in Nunavut, and email invitations 
were sent to principals of all schools located in Nunavut. As a result, eight participants volunteered for the research. In an attempt to involve more participants, additional invitations were sent to Nunavut vice-principals and Nunavut teachers whom the author personally knew, and where the author could travel in an effort to conduct the face-to-face interviews. In turn, six additional participants volunteered for the study. Originally, each participant was to be interviewed two times; however, due to time and geographical restraints, some participants were interviewed once. In accordance with the travel budget, nine interviews were conducted in person, thirteen interviews were conducted over the phone, and two interviews were in the form of written answers to the interview questions. Four participants were Inuit and ten were non-Inuit. Eight participants were female, and six participants were male. To ensure anonymity, pseudonyms are used in place of real names and the participants' community is not identified. See Table 1 for an overview of participant details.

Table 1. Participants

\begin{tabular}{|c|c|c|c|c|}
\hline Pseudonym & Position & Gender & $\begin{array}{l}\text { Number of } \\
\text { Interviews }\end{array}$ & $\begin{array}{c}\text { Inuk/ } \\
\text { Non-Inuk }\end{array}$ \\
\hline Becky & Principal & $\mathrm{F}$ & 2 & Inuk \\
\hline Lucas & Principal & $M$ & 2 & Inuk \\
\hline Isabel & Principal & $\mathrm{F}$ & 2 & Non-Inuk \\
\hline Evelyn & Principal & $\mathrm{F}$ & 2 & Non-Inuk \\
\hline Jack & Principal & M & 2 & Non-Inuk \\
\hline Neil & Principal & $\mathrm{M}$ & 2 & Non-Inukt \\
\hline Chloe & Principal & $\mathrm{F}$ & 2 & Non-Inuk \\
\hline Anna & Principal & $\mathrm{F}$ & 1 & Non-Inuk \\
\hline Henry & Vice-Principal & $M$ & 1 & Non-Inuk \\
\hline Owen & Vice-Principal & M & 1 & Non-Inuk \\
\hline Amelia & Teacher & $\mathrm{F}$ & 1 & Inuk \\
\hline Kylie & Teacher & $F$ & 2 & Inuk \\
\hline Grace & Teacher & $F$ & 2 & Non-Inuk \\
\hline Steve & Teacher & $M$ & 2 & Non-Inuk \\
\hline
\end{tabular}


Griffee (2005) reminds researchers that raw data, such as interview transcripts, do not by themselves reveal meaning; rather, transcripts must be interpreted. In an effort to create meaning, each participant's interview was read in its entirety, gaining familiarity with the overall content. Then each interview was reread, but more systematically, to create categories of key ideas, phrases, commonalities, differences, and patterns that were embedded in the transcripts (Stake, 2005). At this point, emerging categories/patterns were read and reread with the intent to converge the multiple similar categories/patterns into larger theme(s) in response to the research purpose (Miles, Huberman, \& Saldaña, 2014).

Another important aspect of this research is the application of an Indigenous approach to research (Chilisa, 2012; Kovach, 2009). Namely, how were relationships, respect, and relevance for the research conceptualized? The author is employed at the University of Prince Edward Island (UPEI). From 2009 to present, UPEI has offered a Certificate in Educational Leadership in Nunavut program to school principals and educators. Also, from 2009 to 2012, UPEI offered a Master of Education program to two cohorts of Inuit graduate students. Due to these programs, UPEI and Nunavut educator relationships were well-established in many communities across Nunavut. In particular, associated with these programs, the author taught a face-to-face course in Nunavut, has travelled to various communities across Nunavut during additional courses, and has taught an online graduate course to many Nunavut teachers. While teaching, the author listened and took note of the stories she heard and read within assignments. Many interview questions were created based on her students' stories and comments.

\section{Thematic Findings: Contexts and Challenges}

The purpose of this article is to describe the educational contexts and challenges experienced by students and educators who live in Nunavut. The main issue that participants identified was student attendance. Additional barriers included the legacy of residential schools, lack of Inuktitut/Inuinnaqtun resources, and the transience of teachers. These issues are explicated below.

\section{Student Attendance and Underlying Issues}

"The challenge is the attendance, number one" (Jack). When asking participants about obstacles they and/or their students face, most participants identified attendance: Owen explained, "Attendance really drops off in our school around Grade 8-9 ... It's hard to teach someone 
who is only there every other day or who comes late." Other participants also identified attendance as an issue: "Attendance-it is my biggest concern in the North" (Neil). "Try and teach a class that has different kids in it every day" (Chloe). "Attendance is a huge roadblock, and trying to get kids to come to school" (Evelyn). "Attendance, for some kids, we really do struggle with that" (Grace). Becky and Lucas also spoke of student attendance issues within their schools.

Participants also described ways they were attempting to address the attendance challenge. Chloe, a principal, was trying to support her teachers and asked teachers to do more to accommodate late arrivals to the classroom. Chloe perceived that having a student come to school during any time of the day is much better than not having the student come at all. When dealing with students who have attendance issues, Owen shared, "A teacher has to be mindful of the challenges that kids are going through. Kids in our town see stuff that I never saw, and we need to be respectful of that." Neil stated that his school was attempting to get more students to school by having the Inuit school community counsellor and another local teacher, who both speak Inuktitut, visit the homes of students who are often late. These educators are given dedicated time within their work schedule to visit student homes and speak to students and parents/caregivers. Jack stated that he called a general meeting with high school parents to discuss attendance issues. Evelyn explained, "Some of the things we do for attendance are the breakfast programs, stress management, providing student support for kids who needed that extra love and care so that schools would become a place they would want to come."

Although most participants identified student attendance as an issue, when they spoke about attendance, they also described the difficult life experiences that many students have to deal with. Chloe speculated about the underlying cause of attendance issues:

They don't feel engaged. They don't feel welcome. They don't feel like they have a place where they belong, which takes me to what I learned about resiliency ... You need love, they need a relationship with someone, and they need a sense of belonging.

Henry relayed that many of his students, regardless of attendance, come from a home life permeated with issues of poverty, hunger, and/ or unemployment. Isabel explained that, within her community, there 
is "alcohol, drugs, food insecurity, domestic violence ... it's people who don't have money to feed their children. It's gambling problems. It's mental health problems." Kylie recognized, "I have a lot of kids who are going through a lot at home in terms of social services, not being fed." Although participants identified student attendance as an issue, they explained that the issue was connected to diverse aspects of the students' lives. They explained that the issue of attendance needs to be viewed as a part of a larger social problem.

Importance of the Inuit Languages (Inuktitut and Inuinnaqtun)

Most participants emphasized that the Nunavut Department of Education was promoting fluent Inuktitut/Inuinnaqtun and English learners. Participants recognized and valued the importance of maintaining the vitality of the Inuit language. In particular, Jack said:

With language comes culture and with culture comes heritage ... The language is your mother tongue, so if someone takes away your language, you don't exist. Your language brings your culture, and your culture brings your heritage. Heritage means what your generation did, any work, carving, sewing, any cultural things that live for a long time and this gives a heritage to the community.

Also, Lucas stressed, "When we can talk to students in the language they understand, their achievement is much greater because students can work with the language they know. Second language is easier when you have a first strong language."

Participants explained that Inuktitut or Inuinnaqtun is taught in all schools in Nunavut, and the Nunavut Department of Education's vision is to produce bilingual English-Inuktitut/Inuinnaqtun Grade 12 graduates by 2020. Jack explained, "That means [students who] fully read, write, and speak in Inuktitut and fully read, write, and speak in English." Neil also provided background information about bilingualism: "Each community has the power in the [Nunavut] Education Act to determine what their language will be in the school and what sort of program they will use to achieve their goal." As a teacher, vice-principal, or principal, many non-Inuit participants (e.g., Grace, Henry, Owen, Steve, Evelyn, Jack) took conversational Inuktitut courses in an effort to personally show they support the Department of Education's bilingual goal and to learn the basics of the Inuit language. As well, all participants, in one way or another, provided examples of how the Inuit language was an important 
feature of the school environment. Becky believes, "We need to validate the language by using it." Neil noted, "All our signs around the school are bilingual and ... our school notes going home are bilingual. The secretary who answers the phone is bilingual, so she always answers in Inuktitut."

Although this "push to bilingualism" (Owen) was talked about by all participants, they also spoke about challenges related to this goal. Owen pointed out, "It's [Inuktitut/Inuinnaqtun] not spoken as much at home anywhere, and we only have immersion up to Grade 5. That's a barrier we face." Isabel perceived that many upper-elementary students "have half an English and half Inuktitut language," but linguistic abilities to aptly use both these languages is not as high as it should be for the young students.

Notwithstanding this goal of bilingualism, a key challenge is lack of Inuit language resources to support the aim:

We are teaching almost exclusively from Kindergarten to Grade 4 in Inuktitut, but we have very few Inuktitut materials. So the English teacher has a wealth of materials to draw on, whereas the Inuit teacher has very few materials to draw on and has to create most of his or her materials. It puts a lot of pressure on the Inuit teachers. (Neil)

Isabel said, "I am thinking of the Inuk stream versus the English stream ... When I come to the Inuktitut side of things, humongous gaps in curriculum, resources." Chloe explained that the majority of bilingual teachers are in elementary schools, leaving a large void of Inuit staff in the high school. Amelia is an Inuit teacher who is bilingual and taught in the English stream. She spoke of the dual professional pressure she experienced because of a lack of Inuit teachers. In turn, although the participants appeared to place great value on promoting Inuktitut in school, they were frustrated by a lack of formal reading, writing, speaking, and human resources to support the formal teaching of this language.

\section{Residential Schools and Thereafter}

Many of the principals attested to how the legacy of residential schools is an issue that lingers within their school. Jack explained that many Inuit from the past generation lost their children to residential schools, and many modern-day parents still live in the memory of that terror. Lucas noted, "Some parents hesitate to come to the school because of their own bad residential school experiences." Similarly, Amelia stated, "There are some people who are still unable to cope with the residential school effects." 
Neil said, "The residential school legacy still lives on, here in the parents." He went on to explain that because children were taken away from their culture and, immersed in non-Inuit culture, these children grew up to be parents who were not taught traditional Inuit parenting skills. Henry was appreciative of the fact that, in his school, teachers were provided with professional development sessions on the history of residential schools.

Given this residential school history, another educational barrier experienced by many students was lack of parent involvement in school. Chloe observed, "There isn't much parent involvement, unless it's the Christmas concert or those normal things." Steve also said that parental involvement in his school needed to be improved, but indicated, "There are reasons for that." Steve supposed that it was the teachers who were partially responsible for lack of parent involvement:

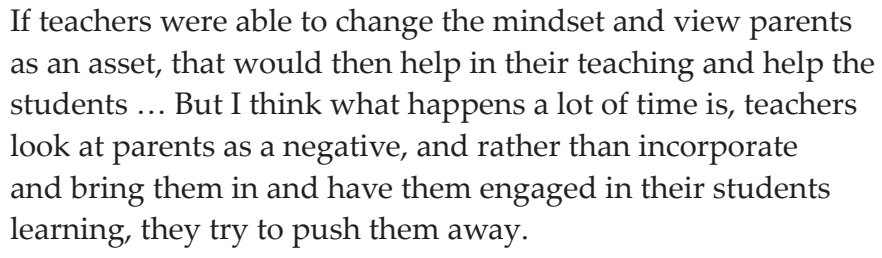

Other participants commented on why parental involvement appeared to be an issue in school. Lucas reasoned that because many Inuit parents never attended a public school like the one their child current attended, the parents do not understand how the school system works. "In turn, they may not support the school because they don't know how. They are not being ignorant. They simply do not know how" (Lucas).

\section{Transient Teachers}

The negative effect of transient teachers was another theme that surfaced during the interviews. Isabel made an important point that was echoed by many other participants. Isabel indicated, "There is a feeling among students that 'I am not going to invest my heart in this teacher who is only going to be here a year."' Similarly, Kylie said, "The kids they know tooyou're not going to be around next year, so why build that relationship? Unfortunately, I hear that." Steve provided details about this issue: 
In Nunavut there have been so many transients in the field of education ... Many come up here to get experience and then move back down south. So many families, Inuit families that have been brought up here, have been exposed to many southerners coming up and being transient. They [the new teachers] will stay for one, two, maybe three years, and then leave.

Henry believed that the constant teacher turnover produced relational strains between educators, students, parents, and community members. Evelyn highlighted that it is not just teacher turnover that is an issue, "there is always at least a third of the principals who are brand new."

Participants spoke about the importance of teachers understanding and getting involved with Inuit culture. With a better understanding of the local context, not only might teachers stay longer, but they are then better able to thread language and culture into the educational experience of students. Participants relayed many successful examples of how Inuit culture and language was immersed in some aspects of the school system. Grace stressed, "We make a good effort in our school to make sure the kids are represented in our classrooms ... Pictures on the wall of not just white Toronto kids." Jack explained that in his school, "They have throat singing, drum dancing, sewing, making amauti [a parka worn by Inuit women], and all these things." Steve explained that in his school, sometimes Inuit Elders would be invited to help students physically build komatik [sled pulled behind a snowmobile or dog team] and meat drying racks. Many participants (e.g., Neil, Steve, Kylie, Lucas, Henry, Owen) described the day- to week-long cultural camps sponsored through the school. Participants explained that students are taken out to the land on snowmobiles and komatik. "There they are supervised by Inuit elders, spoken to only in Inuktitut, and learn about their culture, how people survived in the fall and also in the winter time with the igloo" (Neil). As participants talked about the value of these cultural experiences, they explained that non-Inuit teachers, especially new teachers, need time to experience and understand the culture. An overarching point made by many participants is that when there is a high rate of transiency among teachers, there is a constant need to re-educate each new batch of teachers via lived cultural awareness. Because learning culture is akin to living culture, cultural knowledge takes time to experience and understand. Isabel said, "Those people who stay are the people who are really respected by the local people. The local people can see that they are making this their home." 


\section{Discussion}

The themes of student attendance and a lack of Inuit resources can be analyzed through cultural compatibility theory. Cultural compatibility theory assumes that a student needs to participate in a type of learning experience where that learner can see his/her cultural values and beliefs (Ladson-Billings, 1994). It is about ensuring there is congruence between a student's lived culture and the school experience. Moreover, this alignment of the Inuit student's home culture with school culture positively affects the student's learning. The assertion that local culture needs to be alive within the curriculum and context of the school is strongly supported by international research demonstrating that the preservation, revitalization, and use of Indigenous language and culture among Aboriginal learners are linked to improved educational outcomes (Preston \& Claypool, 2013; Turketo \& Smith, 2014; UNESCO, 2012). Curriculum, pedagogies, and school-related activities all need to be in harmony with the traditional Inuit culture of the students in order to better support student success.

As a part of a culturally congruent (Demmert, 2004) home-school environment, non-Inuit teachers need to discuss the process of privilege, wherein the Westernized knowledge system is often ranked as superior to traditional Indigenous ways of knowing and living (Ladson-Billings, 1994). Otherwise said, actualizing a culturally congruent school-community environment involves teachers decolonizing their pedagogy and schools. McGregor (2013) explained that the decolonization process necessitates teaching and learning approaches that acknowledge and critique structures of power associated with colonization. This power analysis involves the examination of school structures, school policies, school decision-making practices, curricula, pedagogy, assessment practices, and teacher-community involvement, to name a view. This evaluative act is meant to create space, place, and a case for Indigenous ways of knowing, being, and doing. The design of educational programs needs to foster the unique identities of Inuit peoples through the implementation of curricula built upon local Inuit cultures, languages, and knowledge. In doing so, attendance issues within school can be addressed. Also, when parents see their culture within the curriculum, school environment, and educators, they are less likely to be intimidated by schools. Therein, parents can enter a respectable, ethical space, alongside teachers, to address challenges such as attendance issues.

Previous research by Gulati (2013) indicated that many parents and community members in Nunavut continue to experience the lasting 
impacts of residential schools. The legacy of residential schools can also be discussed through cultural compatibility theory. Through this theory, one can examine how past hegemonic powers are directly and tacitly associated with current challenges within the school system. Mary Simon, who was born in Nunavut and was the first Canadian ambassador for circumpolar affairs, indicated, "If we are to restore the trust of [Inuit] parents who have been deeply hurt by their own educational experience, we must build an education system grounded in culture, history and worldview" (as cited in Inuit Tapiriit Kanatami, 2011, p. 4). As reflected in this study, some Inuit parents and caregivers mistrust the education system, and this apprehension may be a reason why some parents are not highly involved in the education of their children. Likewise, Berger's (2009) research showed that Inuit parents and caregivers want more Inuit culture, language, and Elder presence in schools. As mentioned above, if parents and community members feel that the school is lacking or devaluing their traditional culture and identity, it is reasonable to expect that community support is less than optimal. Indeed, teachers assume the formal role of educating the child, but if the teacher's own culture does not reflect the culture of their students, there is often a direct disconnect between how content is taught and what content is taught (Demmert, 2004; Ladson-Billings, 1994). Other research confirms that when Aboriginal peoples self-manage and develop their own Aboriginal-focused curricula, enrolment numbers, retention rates, and overall student satisfaction within these programs increase (Holmes, 2006).

\section{Recommendations and Conclusion}

Across Canada, there is a pronounced need for more Aboriginal teachers (Preston, Cottrell, Pelletier, \& Pearce, 2012; St. Denis, 2010).

Many participants in this study spoke specifically about the shortages of qualified Inuit educators and the high transient rate of non-Inuit teachers in Nunavut. Thus, not only do educational systems need to be concerned with recruiting greater numbers of Inuit teachers, in particular, but the retention of beginning teachers is also a major concern (Watts-Hull, 2004). McGregor (2013) spoke about the challenge of training and retraining sufficient Inuit and non-Inuit educators, administrators, and support staff. Because many teachers leave the profession within the first few years, classrooms are akin to recurrent training grounds, where teachers with some experience leave the profession before becoming experts. In turn, they are often replaced by teachers who, due to their lack of professional and/or Inuit culture experience, perpetuate the cycle and impede the promotion 
of more master-level teachers. The Nunavut Department of Education needs to assist new teachers, helping them to make their Nunavut teaching profession long-term. Canadian and Nunavut government leaders and post-secondary educational institutions must recognize the unique needs of Inuit leaners and make teacher education programs even more accessible to Inuit people. Additional recommendations surface from the results of this study. Since best practices for promoting Aboriginal student success are grounded in relationships (Preston et al., 2015, 2016), principals and educators in Nunavut need to establish innovative ways to create many and varied types of student- and community-focused relationships both inside and outside the school building. To create new and supportive school-community relationships, it is important that school personnel welcome, use, and build on the personal insights of Inuit students, parents/ caregivers, community members, and community organizations.

As a final suggestion, principals, teachers, students, parents/caregivers, and community members may want to create their own "Action Plan for Inuit Student Success" within their school setting. In devising this plan, discussion might focus on assisting staff in promoting a decolonized mindset or world view. As a part of this process, non-Inuit teachers should be willing to learn at least the rudiments of the Inuit language. Berger (2007) explained, "Learning Inuktitut (in western Nunavut, Inuinnaqtun) would help Qallunaat [non-Inuit] teachers understand Inuit culture, the mistakes Inuit learners make speaking English, and the frustration of functioning in a second language" (p. 7). Moreover, it would signal respect for the culture of Inuit students. Dialogue might also focus on such things as indigenizing the curriculum, creating a welcoming school environment for Inuit peoples, promoting leadership opportunities for young Inuit students, and promoting post-secondary education for Inuit students.

Throughout the twentieth century in the Canadian Arctic, many federal leaders, politicians, and bureaucrats recreated the Western institutional, hegemonic systems and structures they employed within the southern parts of Canada. These days, the Inuit people living in Nunavut are ensconced in a social system of leadership, governance, and hierarchy that is radically different from the one their past generations experienced. In turn, the question beckons: How can Inuit culture occupy and engender teaching practices and the Westernized hegemony of the school system? How can a space, a place, and a case for Inuit language, culture, and tradition be better threaded into the school system? In order to make this space, place, and case, teachers must be supplied with professional development opportunities and curricular tools, which imbue the Inuit worldview into 
their practice. Culturally compatible teachers is about teachers of the non-dominant culture understanding, internalizing, reflecting upon, and changing the power imbalances of which they were a part (Shield, Bishop, \& Mazawi, 2005). Consequently, the contextualized findings relayed in this article travel beyond the Inuit setting to intercultural education circumstances where Indigenous or minority cultures are marginalized.

\section{Acknowledgements}

The Social Sciences and Humanities Research Council of Canada provided the funds needed to complete this research.

\section{Author}

Jane P. Preston is assistant professor in the Faculty of Education at the University of Prince Edward Island.

\section{Notes}

1. Since 1953, Northern Affairs and Natural Resources has transformed in name and focus. It is somewhat similar to the current Aboriginal Affairs and Northern Development Canada federal department.

\section{References}

Aylward, M. L. (2007). Discourses of cultural relevance in Nunavut schooling. Journal of Research in Rural Education, 22(7), 1-9.

Aylward, M. L. (2012). The Inuit Qaujimajatuqangit conversation: The language and culture of schooling in the Nunavut territory of Canada. In Z. Bekerman \& T. Geisen (Eds.), International handbook of migration, minorities and education: Understanding cultural and social differences in processes of learning (pp. 213-229). Dordrecht, The Netherlands: Springer.

Berger, P. (2007). Some thoughts on Qallunaat teacher caring in Nunavut. Journal of Teaching and Learning, 4(2), 1-12.

Berger, P. (2009). Eurocentric roadblocks to school change in Nunavut. Études/ Inuit/Studies, 33(1-2), 55-76.

Berger, P., \& Epp, J. R. (2005). “There's no book and there's no guide": The expressed needs of Qallunaat educators in Nunavut. Brock Education, 15(1), $1-14$.

Blake, B. E. (2004). A culture of refusal: The lives and literacies of out-of-school adolescents. New York, NY: Peter Lang.

Bonesteel, S. (2006). Canada's relationship with the Inuit: A history of policy and program development. Ottawa, ON: Minister of Indian Affairs and Northern Development. 
CBC News. (2015, November 18). Arviat high school de-register students for low attendance. Retrieved from http://www.cbc.ca/news/canada/north/ arviat-principal-deregisters-students-low-attendance-1.3323390

Chilisa, B. (2012). Indigenous research methodologies. Thousand Oaks, CA: Sage.

Daitch, S. (2014, January 20). Exposing the dark legacies of residential schools. National Post. Retrieved from http://news.nationalpost.com/full-comment/ sarah-daitch-exposing-the-dark-legacy-of-residential-schools

Demmert, W. G. (2004, October). Improving academic performance among Native American children. Paper presented at the Indian Education Summit, Helena, MT.

Gionet, L. (2014). Inuit in Canada: Selected findings of the 2006 Census. Retrieved from http://www.statcan.gc.ca/pub/11-008-x/2008002/article/10712-eng. htm\#a7

Government of Nunavut, Executive and Intergovernmental Affairs. (n.d.). Inuit employment. Retrieved from http://www.gov.nu.ca/eia/information/ inuit-employment

Griffee, D. T. (2005). Research tips: Interview data collection. Journal of Developmental Education, 28(3), 36-37.

Gulati, S. (2013, June). Literacy matters: Unlocking the literacy potential of Aboriginal peoples in Canada. Retrieved from http://www.td.com/document/PDF/economics/ special/LiteracyMattersUnlockingtheLiteracyPotentialofAboriginalPeoplesinCanada. pdf

Health Canada. (2015). First Nation and Inuit health. Retrieved from http://www. hc-sc.gc.ca/fniah-spnia/promotion/mental/index-eng.php

Holmes, D. (2006). Redressing the balance: Canadian university programs in support of Aboriginal students. Ottawa, ON: Association of Universities and Colleges of Canada.

Indian and Northern Affairs Canada. (2005). Through Mala's eyes: Life in an Inuit community: A learning resource. Ottawa, ON: Minister of Public Words and Government Services Canada.

Inuit Tapiriit Kanatami. (n.d.). Inuit historical perspective. Retrieved from https:// www.itk.ca/about-inuit

Inuit Tapiriit Kanatami. (2011). First Canadians, Canadians first: National strategy on Inuit education. Ottawa, ON: Author.

Kovach, M. (2009). Indigenous methodologies: Characteristics, conversations, and contexts. Toronto, ON: University of Toronto Press.

Ladson-Billings, G. (1994). The Dreamkeepers: Successful teaching for AfricanAmerican students. San Francisco, CA: Jossey-Bass.

Lévesque, F. (2014). Revisiting Inuit Qaujimajatuqangit: Inuit knowledge, culture, language, and values in Nunavut institutions since 1999. Inuit Studies, 38(1/2), 115-136. 
Manning, B. (2013, February 22). Why not teach? Inuit high school students thoughts on becoming teachers. Nunavut Arctic College. Retrieved from http://www.arcticcollege.ca/en/education-news/item/5167-why-notteach/5167-why-not-teach?-researchers-report-on-teacher-education-innunavut $=$

Marshall, C., \& Rossman, G. B. (2011). Designing qualitative research (5th ed.). Los Angeles, CA: Sage.

McGregor, H. E. (2011, July). Inuit Qaujimajatuqangit and the transformation of high school education in Nunavut: History context and statistical profiles of Attagoyuk and Quluaq schools. Iqaluit, NU: Nunavut Government.

McGregor, H. E. (2012). Curriculum change in Nunavut: Towards Inuit Qaujimajatuqangit. McGill Journal of Education, 47(3), 285-302. doi:10.7202/1014860ar

McGregor, H. E. (2013). Situating Nunavut education with Indigenous education in Canada. Canadian Journal of Education, 36(2), 87-118.

Miles, M. B., Huberman, A. M., \& Saldaña, J. (2014). Qualitative data analysis: A methods sourcebook (3rd ed.). Los Angeles, CA: Sage.

National Center for Inuit Education. (2014). Milestone report: National Strategy on Inuit Education: Interim Report on Milestones 2012-2014. Ottawa, ON: Inuit Tapiriit Kanatami.

Niles, M. D., Byers, L., \& Kruegar, E. (2007). Best practice and evidence-based research in Indigenous early childhood intervention programs. Canadian Journal of Native Education, 30(1), 108-125.

Office of the Auditor General of Canada. (2013). 2013 November report of the Auditor General of Canada. Retrieved from http://www.oag-bvg.gc.ca/ internet/English/nun_201311_e_38772.html

Patton, M. Q. (2015). Qualitative research \& evaluation methods (4th ed.). Thousand Oaks, CA: Sage.

Peritz, I. (2014, January 17). Speaking out against $\$ 600$-a-week grocery bills. The Globe andMail.Retrieved fromhttp://www.theglobeandmail.com/news/national/thenorth/why-is-food-so-expensive-in-nunavut-shop-for-yourself-and-find-out/ article15915054/

Preston, J. P., \& Claypool, T. R. (2013). Motivators of educational success: Perceptions of Grade 12 Aboriginal students. Canadian Journal of Education, 36(4), 257-279.

Preston, J. P., Claypool, T. R., Rowluck, W., \& Green, B. (2015). Exploring the concepts of traditional Inuit leadership and effective school leadership in Nunavut (Canada). Comparative and International Education, 44(2), 1-16. Retrieved from http://ir.lib.uwo.ca/cgi/viewcontent. cgi ?article $=1367 \&$ context $=$ cie-eci 
Preston, J. P., Claypool, T. R., Rowluck, W., Green, B. (2016). Perceptions and practices of principals: Supporting positive educational experiences for Aboriginal learners. International Journal of Leadership in Education. dio:10.108 0/13603124.2015.1124926

Preston, J. P., Claypool, T. R., Green, B., \& Rowluck, W. (2015). Principal leadership for Indigenous student success: A multi-case study of principals nurturing relationships. Manuscript submitted for publication.

Rosol, R., C. Huet, M. Wood, C. Lennie, G. Osborne, and G. M. Egeland. (2011). Prevalence of affirmative responses to questions of food insecurity: International Polar Year Inuit Health Survey, 2007-2008. International Journal of Circumpolar Health, 70(5), 488-497.

Ruiz-Castell, M., Muckle, G., Dewailly, E., Jacobson, J. L., Jacobson, S. W., Ayotte, P., \& Riva, M. (2015). Household crowding and food insecurity among Inuit families with school-aged children in the Canadian Arctic. American Journal of Public Health, 105(3), 122-132.

Shields, C., Bishop, R., \& Mazawi, A. E. (2005). Pathologizing practices: The impact of deficit thinking on education. New York, NY: Peter Lang.

St. Denis, V. (2010, March). A study of Aboriginal teachers' professional knowledge and experience in Canadian public schools. Retrieved from http://www.ctf-fce.ca/Research-Library/ABORIGINAL-Report2010-WEB.pdf

Stake, R. E. (2005). Qualitative case study. In N. K. Denzin \& Y. S. Lincoln (Eds.), The Sage handbook of qualitative research (3rd ed., pp. 443-466). Thousand Oaks, CA: Sage.

Statistics Canada. (2013). Aboriginal peoples in Canada: First Nations People, Métis and Inuit. Retrieved from http://www12.statcan.gc.ca/nhs-enm/2011/ as-sa/99-011-x/99-011-x2011001-eng.pdf

Statistics Canada. (2016). Part B: The education and employment experiences of Inuit. Retrieved from http://www.statcan.gc.ca/pub/89-653-x/2013001/article/ part-partie-b-eng.htm

Statistics Canada. (2015). Housing conditions: Crowding. Retrieved from http:// www.statcan.gc.ca/pub/89-645-x/2015001/housing-logement-eng.htm

Tjepkema, M., Wilkins, R., \& Long, A. (2013). Cause-specific mortality by income adequacy in Canada: A 16-year follow-up study. Ottawa, ON: Statistics Canada.

Turketo, K., \& Smith, J. (2014). Promoting achievement for Indigenous students in art education: A New Zealand perspective. Canadian Review of Art Education: Research \& Issues, 41(1), 8-31.

UNESO. United Nations Educational Scientific and Cultural Organization. (2012). Why language matters for the millennium development goals. Bangkok, Thailand: Author. 
Wallace, S. (2014). Inuit health: Selected findings from 2012 Aboriginal Peoples Survey. Ottawa, ON: Statistics Canada. Retrieved from http://www.statcan. gc.ca/pub/89-653-x/89-653-x2014003-eng.pdf

Watts-Hull, J. (2004). Filling in the gaps: Understanding the root causes of the teacher shortage can lead to solutions that work. Threshold, Spring, 8-12, 15.

Yamauchi, L. A. (1998). Individualism, collectivism, and cultural compatibility: Implications for counselors and teachers. Journal of Humanistic Education and Development, 36(4), 189-198. 